\title{
Implications of Belt and Road Initiative for Supply Chain Management: A Holistic View
}

\author{
Atif Saleem Butt ${ }^{1, *}$, Tahseen Anwer Arshi ${ }^{1}\left(\mathbb{D}\right.$, Venkoba Rao ${ }^{2}$ (D) and Veena Tewari $^{2}(\mathbb{D}$ \\ 1 Department of Management, School of Business, American University of Ras Al Khaimah, \\ Ras Al Khaimah 10021, UAE; tahseen.arshi@aurak.ac.ae \\ 2 Faculty of Business Management, Majan University College, P.O. BOX 710, Muscat, Oman; \\ venkoba.rao@majancollege.edu.om (V.R.); veena.tewari@majancollege.edu.om (V.T.) \\ * Correspondence: atif.butt@aurak.ac.ae
}

Received: 16 October 2020; Accepted: 7 November 2020; Published: 8 November 2020

\begin{abstract}
Belt and Road Initiative (BRI), one of the largest logistics and transportation infrastructures to date, has focused on much work in the economics and political sciences. However, little research has been done on how BRI can affect supply chain management on the whole. Since BRI is a large-scale logistics infrastructure-building project, it is clear that it will have several implications for supply chains. This study aimed to fill this gap in supply chain management literature within the context of the BRI. In particular, this paper aimed to unveil the potential challenges and threats that BRI may bring to supply chain management. Using 20 semistructured interviews with supply chain managers located on the BRI lane in South Asian countries (Pakistan, India, Bangladesh, etc.), this study posed six distinct implications of BRI for logistics and supply chain management. This article concludes by articulating its contributions to theory and practice and, finally, limitations and future research directions.
\end{abstract}

Keywords: Belt and Road Initiative; transportation; supply chain management; logistics management

\section{Introduction}

Supply chain management has been the subject of much focus in the past decades [1-5]. These studies attempt to discuss emergent issues and opportunities concerning managing complex supply chains [6,7], management of personal relationships [8-12], and the role of knowledge management in supply chains $[13,14]$. Also, Belt and Road Initiative has gained much attention from the international community. Belt and Road Initiative (BRI) is a fluid concept that encompasses a variety of projects. However, this paper argues that BRI can have a strong impact on the management of supply chains. For instance, BRI can positively affect input or product factors [15-17]. BRI can also affect the cost, logistics, and strategic access. These factors are directly related to infrastructure improvement [18-22]. However, there is a possibility that large geographical distance may give rise to higher interruption through natural disasters [23].

Furthermore, another key goal of BRI is to boost the flow of goods. However, there is still a question as to whether an increase will follow this in the flow of services, finance, and information. Specifically, the last is a crucial prerequisite for efficient product/service flow synchronization and supply chain management $[24,25]$. Shorter lead times are another key consequence of increased commodity flows. While the effect of shorter lead times on supply chains is well studied in the general literature, BRI is unique in that time gap is likely to be minimized independently of geographical distance; and it also allows connections to distant geographical areas rather than improving the speed of the path that is already in operation. 
Moreover, although lead times are shorter due to the BRI, the increased geographical distance will pose new obstacles to supply chain flow management, such as threats of interruption and sustainability concerns. The subject has received extremely limited attention from supply chain management scholars. Despite such varying consequences, the topic has received extremely limited attention from supply chain management scholars. Though China has hundreds of specialist centers that specialize in BRI-related matters, most of them are incorporated into international law, political science, economics, and social sciences [26]. BRI's potential impact on the theory and practice of supply chain management has, thus, been largely overlooked. The BRI's global importance suggests that this is a subject that needs greater focus both inside and outside of China supply chain management's perspective. This research bridges this major void within the sense of BRI in the supply chain management literature. Therefore, the research aim of this report was to expose the consequences of BRI on logistics and supply chain management. The following research question was developed from a review of initial literature: How will BRI impact supply chain management?

We contribute to emergent literature on supply chain management from BRI's perspective in the following ways. First, this study presents different challenges and opportunities that BRI may bring for supply chain management. Second, it contributes to theory by studying its implications from the perspective of supply chain management rather than political science, international law, or economics. Third, the study also provides some constructive guidelines to help firms develop effective policies and practices.

\section{Literature Review}

\section{Impacts of Belt and Road Initiative on Supply Chain Management}

BRI will be an infrastructure project that is likely to have implications for supply chain and logistics management. Studies argue that BRI bears a strong potential to disturb the status quo and deviate the trade from traditional routes, which will raise new challenges and concerns [27-29]. Limited studies appear on BRI's role within the context of supply chain management, explaining how BRI can impact certain factors in supply chain management such as product development, product quality, supply chain resilience, transportation times, and costs. For instance, Hsu [30] studied presented issues about product innovation. This study further outlined linked product development models with implications for its application in the manufacturing sector. Bao and Ma [31] also argue that BRI will impact its quality in parallel supply chains. They further argued that BRI can help manufacturers produce and sell their product to the downstream retailers.

Huang et al. [24] reported that BRI is likely to open access to cheap labor in China's historically isolated western provinces and neighboring countries by 'reducing' perceived geographical distances. Moving on, Chen et al. [17] carried out another analysis using a game theory approach to analyze the competition between modes of freight transport. They also explored how BRI would help minimize freight costs on a wide scale. On the other hand, Ponamarov and Holcomb [32] concluded that BRI could help build more resilient supply chains, such as by enhancing the efficiency and durability of the logistics system. BRI's political importance about stabilizing the supply chain was discussed in another analysis [33]. They argued that China Railway Express' government subsidy program is good for local businesses. Wilhelm et al. [34] argued that BRI would open up the network of companies and locations across China and Asia, thus exposing supply chains from a sustainability perspective to new suppliers that are potentially more remote, immature, and lagging in their growth. Moving on, Karrar [35,36] argued that while BRI will draw and encourage the growth of larger firms, there is already a Silk Road propelled by many independent, informal companies. These studies further stated that a major future research challenge is how to enable these businesses to take advantage of BRI.

In addition, Gallo et al. [37] proposed a mixed model to minimize perishable products' energy consumption. BRI has also been examined concerning its impact on supply chain sustainability. For instance, Lin et al. [38] proposed a BRI model for green supplier selection. 
Supply chain scholars have also examined the role of BRI within the context of supply chain logistics. Particularly, Zhang [39-41] argued that BRI will improve the logistics infrastructure in the cross-bordering supply chain. At the same time, Chen and Yang [42] stated that port cluster problems could be solved. The capacity constraints of the warehouses can be increased through BRI. Also, supply chain scholars need to change the theoretical lens from an economically based one to reflect problems such as institutional pressures if BRI is viewed as a cost of doing business. Future studies should review BRI for this latter paradigm through the neo-institutional theoretical framework. Moving on, Zhao et al. [43] examined the influence of BRI on agricultural products in the southern region of China to understand the associated wastes slowing into bioenergy for energy production. All of these studies use BRI to contextualize their study. They are conceptual, except Cheng and Yang [42]. They suggested a model to evaluate a network's optimum port cluster, the appropriate port capacities, and zonal output size. Using computational tests, the authors applied their model to the container ports along the Maritime Silk Road. See Figure 1 below.

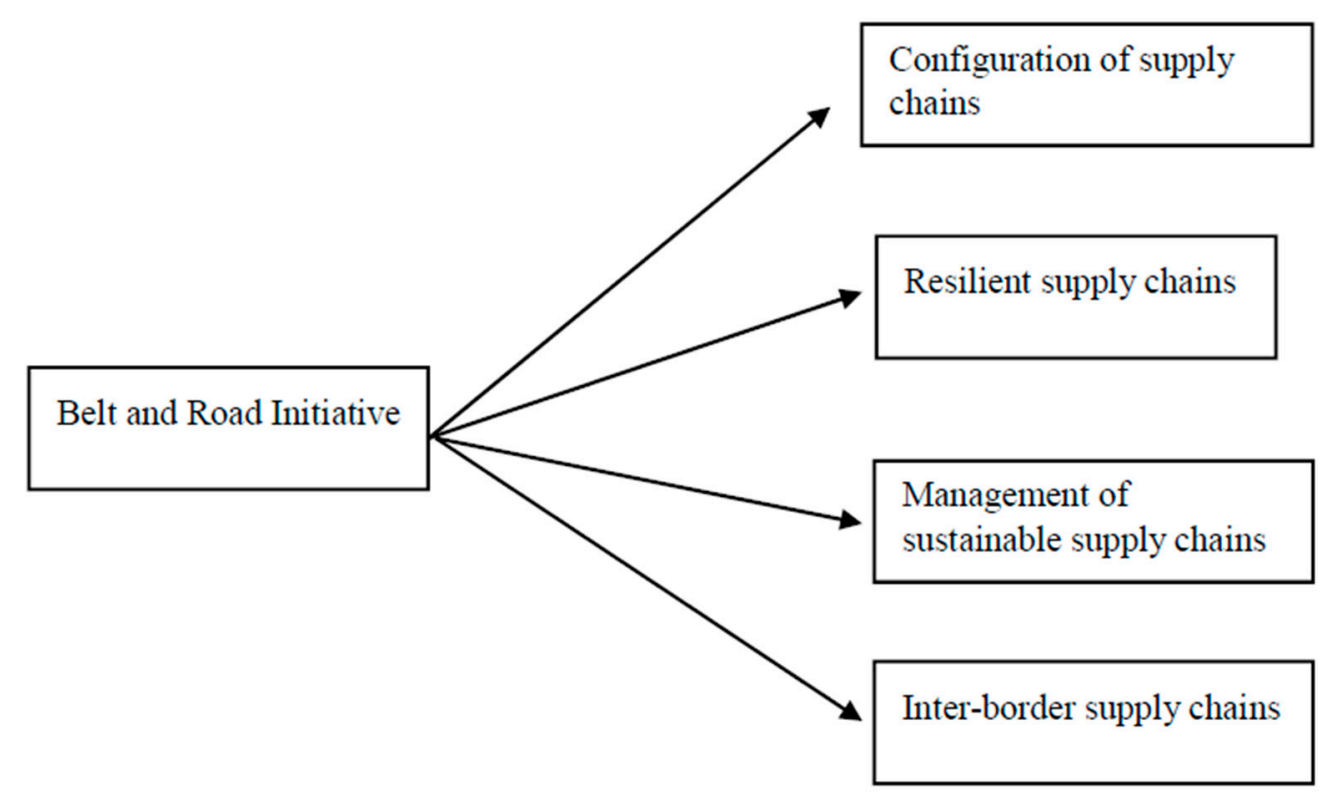

Figure 1. Conceptual framework of the implications of the Belt and Road Initiative (BRI) on supply chain management.

To sum up, while BRI has been the focus of some attention by supply chain scholars, there is limited empirical evidence about how BRI may impact the whole supply chain. Our study attempted to fill this gap. We contribute to an existing knowledge base by unveiling BRI's impact on different supply chain management (sustainable supply chains, resilience, etc.), thus improving our understanding of BRI's implications by taking a holistic view.

\section{Methodology}

\subsection{Sample}

Overall, 20 semistructured interviews were conducted with senior managers from three service providers, two transporters, and two purchasing firms. The companies involved were headquartered in Pakistan, Bangladesh, China, and Sri Lanka. The supplying firms were providing frozen food to their international customers based overseas. The distribution centers were distributing a variety of items including dairy products and plastic materials. Finally, the manufacturing firms were sourcing wooden material from their international suppliers based in China. The senior managers interviewed were designated at different positions such as Operations Manager, Accounts Manager, Sales Manager, Chief Executive Officer, Managing Director, and Procurement Manager. The senior 
managers interviewed in this study had a work experience of over five years and had extensive knowledge around the impact of BRI on the management of supply chain-related projects. In addition, these senior managers had further details about companies' profiles and interviewees, which are provided in Table 1. To begin the process of sampling, we began with purposive sampling. In other words, we used purposive sampling to initiate the process of interviews. Once we successfully conducted the first interview, we asked the participant to put us in touch with another participant who might provide further information on the phenomenon of interest.

Table 1. Profile of companies.

\begin{tabular}{ccl}
\hline \multicolumn{1}{c}{ Firms } & \multicolumn{1}{c}{ Staff } & \multicolumn{1}{c}{ Respondents' Positions } \\
\hline Supplying firm A & $20,000-30,000$ & $\begin{array}{l}\text { Sales Manager (P1) } \\
\text { Area Sales Manager (P2) } \\
\text { Customer Services Manager (P3) }\end{array}$ \\
\hline Supplier firm B & $15,000-20,000$ & $\begin{array}{l}\text { Port Manager (P4) } \\
\text { Senior Area Sales Manager (P5) } \\
\text { Customer Service Manager (P6) }\end{array}$ \\
\hline Supplier firm C & $15,000-20,000$ & $\begin{array}{l}\text { Accounts Manager (P7) } \\
\text { Procurement Manager (P8) } \\
\text { Chief Executive Officer (P9) }\end{array}$ \\
\hline Distributor Centre A & $15,000-20,000$ & $\begin{array}{l}\text { Area Manager (P10) } \\
\text { Managing Direction (P11) }\end{array}$ \\
\hline Distributor Centre B & $20,000-30,000$ & $\begin{array}{l}\text { Operations Manager (P12) } \\
\text { Customer Services Manager (P13) }\end{array}$ \\
\hline Buying firm A & $25,000-30,000$ & $\begin{array}{l}\text { Procurement Manager (P14) } \\
\text { Project Manager (P15) } \\
\text { Procurement Manager (P16) }\end{array}$ \\
\hline Buying firm B & $20,000-30,000$ & $\begin{array}{l}\text { Operations Manager (P17) } \\
\text { Managing Direction (P18) } \\
\text { Procurement Manager (P19) } \\
\text { Logistics Manager (P20) }\end{array}$ \\
\hline
\end{tabular}

\subsection{Data Collection}

Overall, three manufacturing firms, two distribution centers, and two buying firms took part in our study. Furthermore, we interviewed senior managers within these firms only because they had a good knowledge of BRI's impacts on supply chain management. The interviews were conducted from June 2020 until August 2020. After 20 interviews, the new information stopped emerging. We, therefore, stopped any additional data collection and concluded to have reached the point of saturation. It is also imperative to note that all respondents who participated in this study were fully assured of confidentiality during the interview process. Their identities were also anonymized to receive an accurate and unbiased response to the phenomenon of interest. Senior managers from three manufacturing companies, two distribution and transport service provider centers, and two purchasing companies from different participating countries were interviewed on the BRI lane. After 20 interviews, theoretical saturation was reached when new themes stopped appearing. For data collection purposes, 20 interviews were considered to be enough. Throughout the interview process, respondents were ensured anonymity and confidentiality, resulting in a specific and impartial answer to the phenomenon of interest.

\subsection{Data Analysis}

We thoroughly and comprehensively relied on Strauss and Corbin's (1990) paradigm to code and analyzed the data. Once the data collection process was completed, we did a thorough line-by-line analysis to begin open coding. Open coding helped us segregate the data into many discrete events 
and actions and then assign a specific code to each of these. Furthermore, we also facilitated the process of data coding using NVIVO software. Second, we also used axial coding to conduct a deep analysis of each category developed during open coding. Finally, axial helped us to develop a variable of interest only. To ensure the trustworthiness of the findings, the four principles of Guba and Lincoln [44] (credibility, transferability, dependability, and conformability) were strictly followed. We also conducted eight follow-up interviews to enhance the trustworthiness of the study. Figure 2 below illustrates the qualitative research process undertaken for this study.

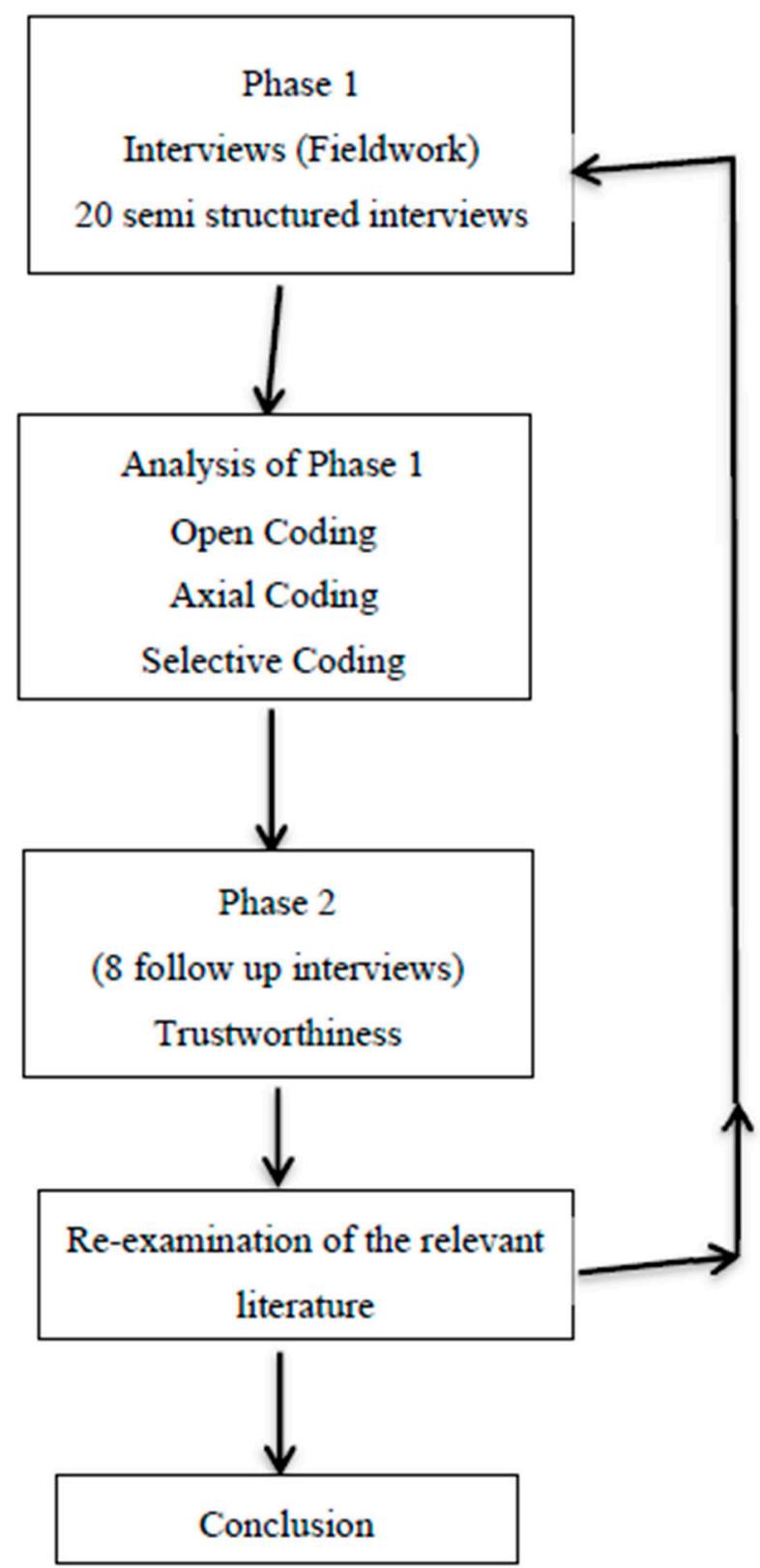

Figure 2. Qualitative research process.

\section{Results}

\subsection{Reduced Geographical Distance and Building Supply Chain Configuration}

Managers' interviews revealed that BRI will have a significant impact on supply chain configuration. Respondents further argued that BRI can play a pivotal role in reducing transportation costs and times. An interview with two respondents (P1 and P7) revealed that BRI would help firms expand 
their operations on a wider scale and they will further be in a position to compete internationally by deciding how to spread activities in its value chain. Furthermore, respondents argue that the biggest challenge that firms face today is how to develop the optimal level of configuration for the products, manufacturing process, and supply sources. Respondents further narrated that BRI will also streamline the firm's ability to make an effective and efficient supply chain that will, at the same time, be in a position to take advantage of different locations and resources and further limit the negative effects of geographical distances.

Contrary to the above arguments, three respondents (P7, P8, and P9) revealed that BRI will reduce transportation timings across countries; however, there is a negative side associated with it. That is, BRI will enable access to cheap labor in China (particularly China's remote areas) and neighboring countries, due to shrinkage in geographical distances. This will adversely affect low-wage and developing economies, which are now moving forward to developed nations like Bangladesh and India. In other words, these countries might lose an opportunity to provide enough employment to their people as most of the workforce will remain limited to remote Chinese areas. These respondents narrated that different countries would be required to form a geographical perspective to stay connected.

Additional interviews with respondents support the above results. These respondents narrated that BRI will help businesses better organize their supply chain networks and process to achieve their operational and strategic goals. For instance, BRI will strengthen the coordination plans, mainly focusing on hard infrastructure like roads, high-speed railways, marine routes, and pipelines as well as energy generation projects. Respondents further narrated that BRI will also result in reduced lead times at a low cost. BRI will also have a positive impact on the inventory placement decision as part of the supply chain. Respondents further narrated that manufacturers nowadays are under heavy pressure to reduce the cost and time associated with developing the product and the quality and functionality. BRI will also allow manufacturers to develop products within the minimum time frame without compromising the quality. It will open up a new avenue for manufacturers to interact with suppliers at different supply chain stages. Furthermore, BRI will significantly impact the supply chain configuration at an early stage of product development concerning managing inventory and stock placement issues in the supply chain. An excerpt from the interview of one of the participants (P3) reveals that Belt and Road Initiative will reduce transportation times among widely spread countries. It will also improve supply chain practices among the firms by reducing excess inventory and stocks.

\subsection{Efficient Supply Chain Resilience}

Interviews with respondents unveiled that BRI can contribute significantly to enhancing supply chain resilience. For instance, P3 and P4 reported that BRI could result in more significant and established resilience in supply chains, increasing the logistics infrastructure's quality and dependability. This respondent further argued that one of BRI's main goals is to build the latest and cutting-edge logistics infrastructure, improving supply chain resilience. This interviewee also argued that BRI will also increase visibility and further enhance collaboration among supply chain firms through greater connectivity. This respondent argued that BRI could contribute through policy making on how infrastructure should be developed and provide a high resilience to supply chains that will rely on this infrastructure. These respondents further revealed that BRI will enable supply chains to prepare and effectively respond to disruptions in a timely and most effective way. This respondent further argued that BRI will result in building large-scale logistics infrastructure and capabilities, which can be built successfully for supply chain resilience, specifically in complex supply chains, and BRI would add value to this very long-complex issue.

Additional interviews with respondents revealed that BRI can improve supply chains through enhanced infrastructure built over the years among partnering countries. Besides, BRI will be in a better position to accommodate disruptions as there will be more suppliers and buyers in the global market, which will make it easy for customers to switch suppliers or if they have to redesign their product. Furthermore, BRI will provide a competitive advantage to the supplying firms and will 
further reduce customer perception of assumed risk and move companies to risk resiliency. An excerpt from the interview of $\mathrm{P} 2$ provides support to the above findings. This respondent argued that the highly developed infrastructure can play an important role in building resilient supply chains.

Well, I can certainly tell you that BRI is going to develop high-quality roads, railway, and transport networks. In fact, this is one of the main objectives of BRI. Such an effective and efficient network will help firms to respond effectively to any disruptions. It will even support firms in becoming more and more competitive, which is indeed a positive sign.

\subsection{Threats to Supply Chain Resilience}

Some respondents also argued that BRI can also pose a threat to effective supply chain resilience through difficulty managing infrastructure. These are discussed in detail below.

\section{Maintenance of Infrastructure}

Respondents also argued that BRI can threaten firms willing to be supply chain resilient as challenges will always remain there concerning managing or maintaining the infrastructure. These respondents narrated that this is particularly important for remote areas where firms lack access to required resources to remain resilient. Additional interviews with respondents provided similar stories about how managing logistics infrastructure could be challenging due to BRI. For instance, P9, P10, and P13 reported that firms must never forget that the disruptions in supply chains occur not only through unpredictable or unforeseen circumstances/conditions, but they can also emerge through the slow destruction of the actual physical infrastructure. This slow erosion may result in less effective infrastructure or perhaps leading to a complete disruption. For instance, roads, rail networks, and bridges can collapse if not taken care of properly, which can adversely affect the logistics facilities and routes among the partnering nations. These respondents (in contrast to what other respondents mention of the benefits attributed to BRI) raised a concern that firms should invest in understanding a complete and detailed view of how BRI is going to impact the supply chain resilience as it does not make sense to only discuss how BRI can positively impact logistics infrastructure.

\subsection{Issues Affecting Supply Chain Sustainability}

Many respondents narrated that BRI can affect supply chain sustainability through social issues. These are discussed below.

\section{Social Issues}

Interviews with respondents revealed that BRI is not only likely to affect the environment, but it can also adversely affect social issues such as human rights, health, and safety as well as community initiatives. Three respondents narrated that BRI will increase the pool of firms across different nations and countries, which will make it difficult for the practices organizations usually adopt to detect and further rectify social problems in the supply chain networks. These respondents further argued that firms will lack opportunities to detect any social problems in supply chains. For instance, firms might find it challenging to conduct audits against the suppliers' code of conduct or, in other instances, might struggle with approaching suppliers having third-party certifications. Respondents also argued that because of the wide network of firms and locations resulting from BRI, buyers will struggle to develop any remediation plan in place, such as more regular audits and perhaps conducting and arranging training sessions on the value associated with the social reforms.

Additional interviews with four respondents revealed similar stories. They contended that BRI will generate more social issues, which will affect supply chain sustainability. For instance, a detailed discussion with these respondents revealed that as BRI will open up more locations and networks of firms across China and Asia. This will expose the supply chain to a pool of new and immature suppliers. Furthermore, such suppliers could be based on partner countries' remote areas and lag in their sustainable development and meeting buyers' demand. Furthermore, respondents narrated that 
buying firms are usually familiar with supplying firms' locations (i.e., where and how their products are made and the prevailing conditions under which production occurs). BRI will pose a risk in buying firms to fully understand the supplying firms' business operations. Moreover, that will be even more challenging when dealing with suppliers located in geographically remote areas, specifically developing economics. Respondents closed the discussion by stressing that firms are unsure whether BRI will improve or deteriorate the overall transparency in supply chains. Consider an excerpt from one of the participants (P7).

My point is that BRI will make it extremely difficult for firms to work with suppliers who can fully comply with the quality requirements. This is even truer for suppliers based in remote areas of developing countries participating in BRI.

\subsection{Managing Cross-Border Supply Chain Management}

Interestingly, many respondents revealed that one of the most important aspects that make a supply chain, which is rooted in characteristics of BRI, is a dire need to effectively manage a cross-border supply chain, especially among the developing nations. These respondents narrated that firms are aware of the risks and challenges that emerge when handling cross-border supply chains in developed countries. However, there is a risk associated with managing cross-border supply chains in developing countries. Specifically, smaller firms in these developing countries, including many central Asian countries, do not have the full potential to rely on external support from logistics providers or third-party logistics providers. These respondents argued that BRI targets and works to foster and develop large firms and further neglects to invest in small-scale firms. So how firms can develop themselves in BRI is a further investigation and needs further attention as BRI moves further.

Additional interviews with respondents (P12, P14, P15, and P19) revealed that firms need to carefully evaluate potential implications that would be brought into cross-border trade due to BRI. These respondents argued that while larger firms will survive, small firms might struggle with connectivity and multi-modal logistics and increase overall trade growth. Furthermore, these respondents also stated that BRI is expected to transform the trade due to infrastructure developments and further increase cross-border growth and economic development. This leverage might only be limited to already established countries. Consequently, countries need to transform their small firms to give them enough room to experience cross-border growth.

\subsection{Disposition of BRI}

Perhaps, one of the most important points that can be inferred from a detailed discussion on supply chains is how/whether the supply chain would accept the change or not. Different firms are perceiving BRI in different ways. For instance, some respondents portrayed BRI as a sort of infrastructural innovation: a substantial and perhaps a radical change in the creation and management of roads, trains, and air networks. However, respondents raised a caution that if you view BRI as an infrastructural innovation and something that is completely going to change the supply chain's flow, one must remain mindful that managing such flows will require a different set of criteria.

Further discussion with two more respondents provides similar stances on the deployment of BRI. For instance, they argued that if BRI is viewed as an "innovation", several issues can emerge. For instance, factors that can potentially affect the adoption and diffusion of BRI's new infrastructure and the decision's adoption timing. These respondents also argued that BRI can be viewed as the cost of doing business besides an innovation. However, suppose BRI is going to increase the cost of doing business for firms from partnering countries. How these costs can be minimized in a supply chain requires attention.

Additional interviews with respondents raised concerns related to how the deployment of BRI could be a big challenge. For instance, three respondents (P8, P9, and P18) contended that one of the biggest challenges that supply chain firms face is responding to BRI changes. For instance, changes in trade diversion efficiency of logistics will affect the border process, which might not be fully accepted 
by the supply chain member firms. These authors also argued that firms need to be cautious enough about and need to ponder whether they will accept or reject the changes that could be expected once BRI has rolled over the participating countries. Figure 3 below provides the summary of the results.

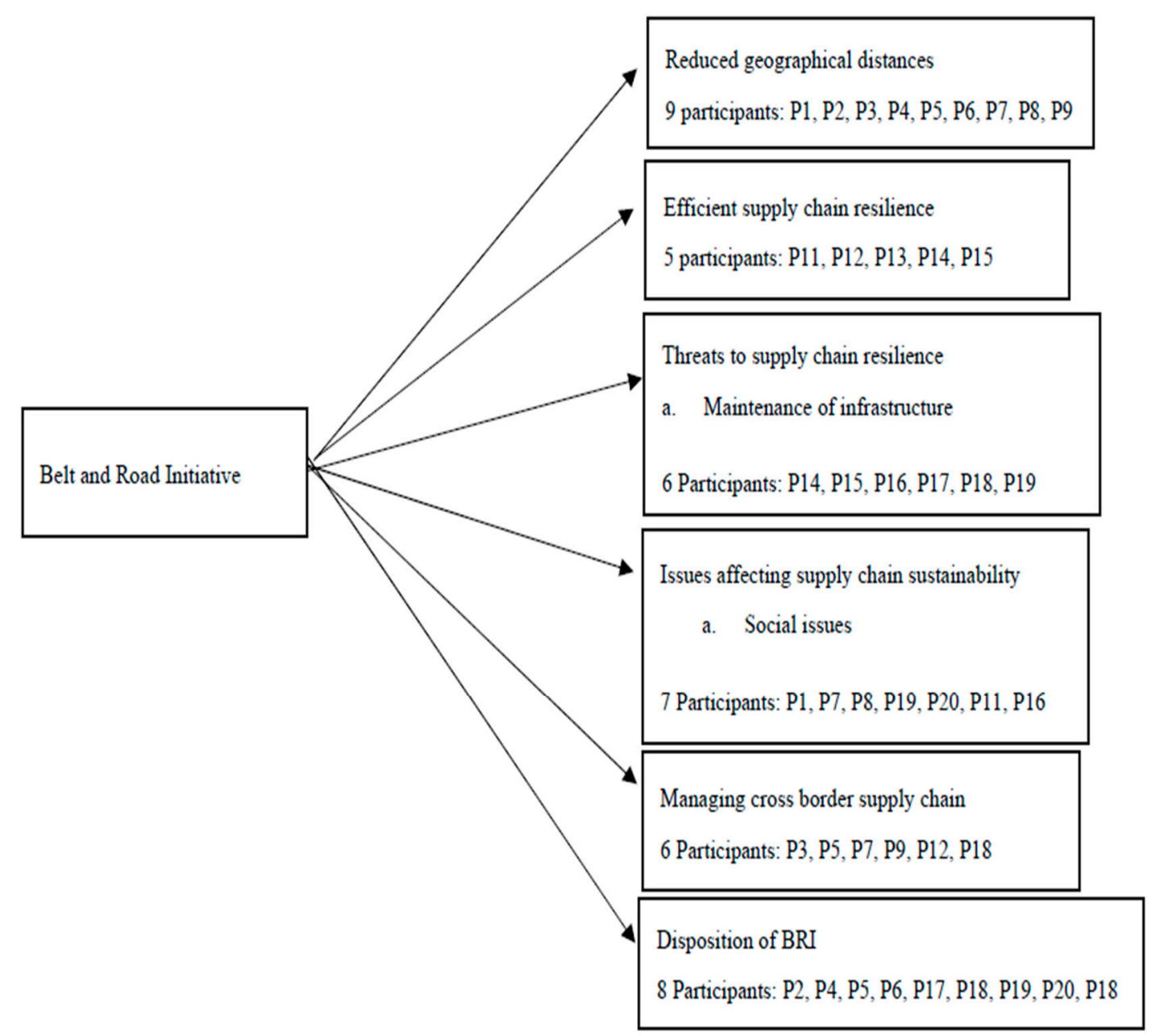

Figure 3. Proposed model of the impact of BRI on supply chain management.

\section{Implications for Theory}

This is perhaps the first research that offers analytical proof of BRI's effect on supply chain management prototypes. Results suggest, in particular, that BRI will impact supply chain management in six major distinct ways. In the beginning, BRI would enhance the configuration of the supply chain by shortened transport times, while at the same time adding numerous, complex sources of risk (inherent political threats and difficulties in the management of logistics infrastructure) are introduced, which calls for more research on supply chain resilience $[7,17,19,30,31,33,45]$. BRI may also harm the climate and other societal considerations, such as the frequent checks of suppliers and the results of adequately accredited suppliers, as many suppliers could be based in the remote areas of BRI roads. Besides, cross-border supply chain management for small- and medium-sized businesses in developed countries could also be impacted by the BRI. Finally, there is a concern about whether businesses within the supply chain would approve or oppose the improvements resulting from the BRI.

Another contribution of this paper is that it delves further into BRI's expected effect on the multiple variables deciding the decisions on position and supply chains' movement. Ellram [46] argued, for example, that considerations such as expense, workforce, logistics, supply chain instability, and country risk may affect the location decisions of the businesses. Study results offer empirical evidence for some of the core problems described by Ellram [46]. When deciding on locations with 
BRI, businesses will experience that. For example, Ellram [46] argued that the BRI would increase primary capital access for businesses. This research gives observational proof that BRI can assist businesses in obtaining access to additional capital. The results also support the claims raised by Ellram [46] empirically, which may affect the company's decision on location decisions, such as improved availability and transport efficiency, higher risk through bilateral relationships, and, finally, firms' increase of firms' access to suppliers and markets between developing economies.

\section{Implications for Practice}

This study has direct practical implications as well. It highlights the benefits that supply chain management can enjoy as a result of BRI. Moreover, it also highlights key issues and challenges that supply chain management might incur within the context of BRI. First, BRI can increase the complexity of supply chain decisions. Different firms, depending on their size and integration into BRI, will respond to the changing supply chain management needs in different styles. Perhaps one of the most notable points that this study raises is how firms will respond to the changes as this will shape the competitive landscape and further define which firms will be successful and become a victim of failure in the BRI era. Therefore, at the outset, this paper suggests firms be very careful when they become a part of BRI and think twice about how they will opt for and respond to the changes (gaining access to more resources or accessing suppliers in remote areas). This is particularly important for small-scale firms as they will not have access to many resources. At the same time, BRI will serve as a unique platform for logistics companies to boost their market and contribute to the success of BRI, while at the same time, buying firms can struggle to find and develop a relationship with suppliers in the remote areas, particularly in developing economies. Besides, supplying firms' social issues will also peak (whether manufacturers meet product quality standards). Therefore, this study suggests buying firms ensure that they approach and work with suppliers with proper certifications or encourage suppliers to seek required certifications. This paper also argues that firms should emphasize the need for more transparency in supply chains as this will let buyers and the end consumers fully understand their products' provenance.

Furthermore, the onus is on suppliers to provide all up-to-date and full-fledged information to the firms on how and under what conditions they make products. This will result in enhanced supply chain sustainability. Results also suggest that small firms may find it difficult to engage in the cross-border supply chain in developing economies in the context of BRI. Therefore, we suggest that the government encourage small firms to foster their development and eventually become a larger enterprise. Results also suggest that BRI might not necessarily bring benefits to the participating countries. It can increase the country's expenditure, and the cost of doing business may go up. Firms should, therefore, be cautious to fully evaluate their situation before adopting BRI.

\section{Discussion}

While many studies exist in the supply chain domain on the role of BRI [37,47-49], most of them use BRI as a context only for work conducted on other topics, and there is no empirical evidence to support the claims raised. Indeed, BRI is a mega project and unique phenomenon of this time, worthy of observation, and demands empirical work specifically to BRI's implication on supply chains and logistics management (access to resources, reducing excess production capacities, and location decisions for manufacturing, etc.). Indeed, the Belt and Road Initiative, one of the largest infrastructure projects undertaken so far in the 20th century, has been a subject of keen attention in other disciplines/fields such as economics and finance. Its application to the supply chain and logistics domain has been nonexistent, even though it is clear that one of the main objectives of BRI is to develop a quality logistics infrastructure. Therefore, this article's main purpose was to explore the impact of the Belt and Road Initiative on the supply chain and logistics management. The results highlight that BRI certainly has the potential to affect many aspects of supply chain management. For instance, the first and predominant issues could be related to the supply chain configuration. In particular, 
results suggest that BRI will shrink the geographical distances and China's infrastructure investment in other countries for those countries to make use of their cheap labor. This will create imbalance once again between China and other developing economies. In addition, while BRI will shorten the lead times, increased geographical distance raises new challenges to managing supply chain flows, such as disruption risks and sustainability issues. This study also debates that while BRI will improve supply chain resilience through the development of quality infrastructure, it also poses future challenges in political terms and to managing logistics infrastructure in the long run. These findings support a study by Diener [50] and Tahseen and Owen [51] on BRI's role in supply chains. This study argued that BRI's infrastructure is very distinct and possess inherent risks. Furthermore, this study's results are unique because it takes a holistic and thorough review of the supply chain instead of just focusing on a single aspect such as resilience or sustainability. We, therefore, argue that our results offer much deeper and more comprehensive understanding of the phenomenon.

Furthermore, this study argues that BRI will also adversely impact environmental and social factors, which will pose future challenges to maintain supply chain sustainability. These findings are consistent with a recent study conducted by Zhao et al. [43] on green supply chains, arguing that BRI will result in higher pollution and wastage dissemination. Other studies also argued that BRI might pose a serious threat to the management of sustainable supply chains as BRI comes with several potential environmental and social risks, which might be difficult to address. Furthermore, firms within supply chains will find it challenging to find suppliers who can meet their expectations when making regular audits. Data analysis also suggests that smaller firms or perhaps small- and medium-sized enterprises, specifically within Asian countries, might not be able to counter management cross-border supply chain management effectively as BRI comprises a global and multi-country context and only favors larger firms. Finally, and perhaps, the real challenges lie in the fact of the extent to which supply chain member firms can adopt or reject the changes brought by BRI, as different participants presented different perceptions regarding BRI (for instance, some regarded BRI as an "innovation" from individual perspective while some treat it as "diffusion").

\section{Conclusions, Limitations, and Future Research Directions}

There are some drawbacks to this study. First, this study focused on 20 interviews in a small-scale sample. It was also not possible to generalize the findings to the larger population. Second, this study selected the sample size only situated on the BRI lane from Asian countries. In this developing field, there are more avenues for potential study. Next, the results of this thesis should be tested to show its conformity by quantitative examination. Furthermore, because of its minimal or restricted access to human and natural resources, BRI offers access to a portion of the planet that has been ignored for many years. Therefore, future research should explore how to create sustainable and resilient supply chains that can connect developed economies with developing economies.

Besides, this mega-infrastructure program's obstacles and benefits are likely to be special and distinct within a single nation from smaller infrastructure projects. Future studies should then aim to expose the particular challenges involved with BRI and investigate alternative ways to resolve these concerns. Carrying out such studies (identifying issues and suggesting solutions) will offer valuable insights into other global development initiatives that might appear over the next two to three decades. Some scholars have also argued that certain factors could influence the implementation of BRI's digital technology.

Furthermore, it is possible to view BRI as an activity for economic gain to give a certain boost to the country's GDP or, perhaps, it can result in higher expenditure for the given economy. Hence, prospective work on future studies must see whether BRI can be viewed as an economic advantage or even an expense associated with doing business in developed countries. Most importantly, BRI is a concept that is fascinating but requires analytical work. Therefore, future studies should research this subject area and ask what BRI means for supply chain management literature. 
Author Contributions: Conceptualization, A.S.B. methodology, A.S.B.; software, A.S.B. and T.A.A.; validation, A.S.B. and T.A.A.; formal analysis, A.S.B.; investigation, T.A.A.; resources, T.A.A.; data curation, A.S.B.; writing-original draft preparation, A.S.B.; writing—review and editing, A.S.B.; visualization, V.R. and V.T.; supervision, A.S.B.; project administration, A.S.B.; funding acquisition, T.A.A. All authors have read and agreed to the published version of the manuscript.

Funding: This research received no external funding.

Conflicts of Interest: The authors declare no conflict of interest.

\section{References}

1. Scholten, K.; Scott, P.; Fynes, B. Mitigation Processes-Antecedents for Building Supply Chain Resilience. Supply Chain Manag. 2014, 19, 211-228. [CrossRef]

2. Stock, G.N.; Greis, N.P.; Kasarda, J.D. Enterprise logistics and supply chain structure: The role of fit. J. Oper. Manag. 2000, 18, 531-547. [CrossRef]

3. Tukamuhabwa, B.R.; Stevenson, M.; Busby, J.; Zorzini, M. Supply chain resilience: Definition, review and theoretical foundations for future studies. Int. J. Prod. Res. 2015, 53, 5592-5623. [CrossRef]

4. Butt, A.S.; Shah, S.H.H.; Sheikh, A.Z. Is guanxi important in a buyer-supplier relationship? Case of Chinese logistics industry. J. Asia Bus. Stud. 2020, 14, 1-14. [CrossRef]

5. Butt, A.S. Personal relationships and higher agency costs: A study of buyers and suppliers in the Australian manufacturing and service sector. Oper. Supply Chain Manag. 2018, 11, 140-150. [CrossRef]

6. Mentzer, J.T.; de Witt, W.; Keebler, J.S.; Min, S.; Nix, N.W.; Smith, C.D. Defining supply chain management. J. Bus. Logist. 2001, 22, 1-25. [CrossRef]

7. Butt, A.S. Antecedents of knowledge hiding in a buyer-supplier relationship. Knowl. Process Manag. 2019, 26, 346-354. [CrossRef]

8. Butt, A.S. Guanxi and intra-organizational conflicts: Evidence from the Chinese logistics industry. Manag. Res. Rev. 2019, 42, 495-505. [CrossRef]

9. Butt, A.S. Mitigating knowledge hiding in a buyer-supplier relationship: An exploratory study. Knowl. Process Manag. 2020, 27. [CrossRef]

10. Butt, A.S. Consequences of top-down knowledge hiding: A multi-level exploratory study. VINE J. Inf. Knowl. Manag. Syst. 2020b. [CrossRef]

11. Noor, S.; Guo, Y.; Shah, S.H.H.; Nawaz, M.S.; Butt, A.S. Research Synthesis and Thematic Analysis of Twitter Through Bibliometric Analysis. Int. J. Semant. Web Inf. Syst. (IJSWIS) 2020, 16, 88-109. [CrossRef]

12. Butt, A.S.; Ahmad, A.B. Personal relationship and conflicts in supply chains: Exploration of buyers and suppliers in Australian manufacturing and service sector. Benchmarking 2019, 26, 2225-2241. [CrossRef]

13. Noor, S.; Guo, Y.; Shah, S.H.H.; Nawaz, M.S.; Butt, A.S. Bibliometric analysis of social media as a platform for knowledge management. Int. J. Knowl. Manag. (IJKM) 2020, 16, 33-51. [CrossRef]

14. Butt, A.S.; Ahmad, A.B. Strategies to mitigate knowledge hiding behavior: Building theories from multiple case studies. Manag. Decis. 2020. [CrossRef]

15. Chaisse, J.; Matsushita, M. China's Belt and Road'Initiative-Mapping the World's Normative and Strategic Implications. J. World Trade 2018, 52, 163-186.

16. Summers, T. China's 'New Silk Roads': Sub-national regions and networks of global political economy. Third World Q. 2016, 37, 1628-1643. [CrossRef]

17. Chen, X.; Zhu, X.; Zhou, Q.; Wong, Y.D. Game-Theoretic Comparison Approach for Intercontinental Container Transportation: A Case between China and Europe with the B\&R Initiative. J. Adv. Transp. 2017, 2017, 1-15.

18. Holslag, J. How China's New Silk Road Threatens European Trade. Int. Spect. 2017, 52, 46-60. [CrossRef]

19. Butt, A.S. Absence of personal relationship in a buyer-supplier relationship: The case of buyers and suppliers of logistics services provider in Australia. Heliyon 2019, 5, 1-5. [CrossRef]

20. Butt, A.S. Determinants of top-down knowledge hiding in firms: An individual-level perspective. Asian Bus. Manag. 2019. [CrossRef]

21. Butt, A.S. Consequences of top-down knowledge hiding in firms: A pilot study. Heliyon 2019, 5, 1-5. [CrossRef]

22. Butt, A.S. Mitigating knowledge hiding in firms: An exploratory study. Balt. J. Manag. 2020, 15, $631-645$. [CrossRef] 
23. Chen, X. Globalisation redux: Can China's inside-out strategy catalyse economic development and integration across its Asian borderlands and beyond? Camb. J. Reg. Econ. Soc. 2018, 11, 35-58. [CrossRef]

24. Huang, Y. Understanding China's Belt \& Road Initiative: Motivation, framework and assessment. China Econ. Rev. 2016, 40, 314-321.

25. Chen, J.; Sohal, A.; Prajogo, D. Supply chain operational risk mitigation: A collaborative approach. Int. J. Prod. Res. 2013, 51, 2186-2199. [CrossRef]

26. Kolosov, V.A.; Suocheng, D.; Portyakov, V.Y.; Chubarov, I.G.; Tarkhov, S.A.; Shuper, V.A. The Chinese Initiative "The Belt and Road": A Geographical Perspective. Geog. Environ. Sustain. 2017, 10, 5-20.

27. Butt, A.S.; Ali, I. Understanding the implications of Belt and Road Initiative for sustainable supply chains: An environmental perspective. Benchmark. Int. J. 2020, 27, 2631-2648. [CrossRef]

28. Butt, A.S.; Ahmad, A.B.; Shah, S.H.H. Knowledge hiding in a buyer-supplier relationship: A pilot study. Knowl. Process Manag. 2020. [CrossRef]

29. Butt, A.S.; Shah, S.H.H.; Noor, S.; Ali, M. Knowledge Hiding in a Buyer-Supplier Relationship-Present and Future Scope. Int. J. Knowl. Manag. 2020, 16, 18-29. [CrossRef]

30. Hsu, M.W. An Analysis of Intention to Use in Innovative Product Development Model through TAM Model. Eurasia J. Math. Sci. Technol. Educ. 2016, 12, 487-501. [CrossRef]

31. Bao, B.; Ma, J. Dynamic Game Behavior of Retailers Considering the Quality of Substitute Products Based on Delay Decision. Int. J. Bifurc. Chaos 2017, 27, 175-206. [CrossRef]

32. Ponomarov, S.; \& Holcomb, C. Understanding the concept of supply chain resilience. Int. J. Logist. Manag. 2009, 20, 124-143. [CrossRef]

33. Du, Q.; Shi, X. A Study on the Government Subsidies for C.R. Express Based on Dynamic Games of Incomplete Information. Period. Polytech. Transp. Eng. 2017, 45, 162-167. [CrossRef]

34. Wilhelm, M.M.; Blome, C.; Bhakoo, V.; Paulraj, A. Sustainability in multi-tiersupply chains: Understanding the double agencyroleof thefirst-tier supplier. J. Oper. Manag. 2016, 41, 42-60. [CrossRef]

35. Karrar, H.H. Merchants, Markets, and the State. Crit. Asian Stud. 2013, 45, 459-480. [CrossRef]

36. Karrar, H.H. The Resumption of Sino-Central Asian Trade, c.1983-94: Confidence Building and Reform Along a Cold War Fault Line. Cent. Asian Surv. 2016, 35, 334-350. [CrossRef]

37. Gallo, A.; Accorsi, R.; Baruffaldi, G.; Manzini, R. Designing Sustainable Cold Chains for Long-Range Food Distribution: Energy-Effective Corridors on the Silk Road Belt. Sustainability. 2017, 9, 2044. [CrossRef]

38. Lin, J.Y.; Wang, Y. Development beyond aid: Utilizing comparative advantage in the Belt and Road Initiative to achieve win-win. J. Infrastruct. Policy Dev. 2017, 1, 149-167. [CrossRef]

39. Zhang, Y. Research on the Innovative Mode of Regional Economic Cooperation in the Construction of the Belt and Road. Boletín Técnico 2017, 55, 121-127.

40. Zhang, L.; Chen, T.; Yang, J.; Cai, Z.; Sheng, H.; Yuan, Z.; Wu, H. Characterizing copper flows in international trade of China, 1975-2015. Sci. Total Environ. 2017, 601, 1238-1246. [CrossRef] [PubMed]

41. Zhang, Z.; Zhao, Y.; Su, B.; Zhang, Y.; Wang, S.; Liu, Y.; Li, H. Embodied Carbon in China's Foreign Trade: An Online SCI-E and SSCI Based Literature Review. Renew. Sustain. Energy Rev. 2017, 68, 492-510. [CrossRef]

42. Chen, D.; Yang, Z. Systematic optimization of port clusters along the Maritime Silk Road in the Context of Industry Transfer and Production Capacity Constraints. Transp. Res. Part E 2018, 109, 174-189. [CrossRef]

43. Zhao, C.; Zhang, H.; Zeng, Y.; Li, F.; Liu, Y.; Qin, C.; Yuan, J. Total-Factor Energy Efficiency in BRI Countries: An Estimation Based on Three-Stage DEA Model. Sustainability 2018, 10, 278. [CrossRef]

44. Guba, E.G.; Lincoln, Y.S. Competing paradigms in qualitative research. Handb. Qual. Res. 1994, 2, 105.

45. Butt, A.S. Personal relationships in supply chains. Int. J. Integr. Supply Manag. 2019, 12, 193-204. [CrossRef]

46. Ellram, L.M.; Tate, W.L.; Petersen, K.J. Offshoring and reshoring: An update on the manufacturing location decision. J. Supply Chain Manag. 2013, 49, 14-22. [CrossRef]

47. Lee, S.; Cho, J. Optimal number of ports and implications for Korea's port policy. J. Korea Trade 2017, 21, 56-68. [CrossRef]

48. Hu, D.; Ou, J.; Hu, X. On the Environmental Responsibility of Chinese Enterprises for Their FDIs in Countries within the One Belt and One Road Initiative. Chin. J. Comp. Law 2017, 5, 36-57. [CrossRef]

49. Hu, R.W. China's 'One Belt One Road' Strategy: Opportunity or Challenge for India? China Rep. 2017, 53, 107-124. [CrossRef] 
50. Diener, A.C. Parsing mobilities in Central Eurasia: Border management and New Silk Roads. Eurasian Geogr. Econ. 2015, 56, 376-404. [CrossRef]

51. Tahseen, A.A.; Owen, D.G. A pilot study to evaluate the potential and value for ehananced operations and project management learning in Omani Companies. Int. J. Humanit. Soc. Sci. Conf. Ed. 2014, 1, 9-26.

Publisher's Note: MDPI stays neutral with regard to jurisdictional claims in published maps and institutional affiliations.

(C) 2020 by the authors. Licensee MDPI, Basel, Switzerland. This article is an open access article distributed under the terms and conditions of the Creative Commons Attribution (CC BY) license (http://creativecommons.org/licenses/by/4.0/). 